\title{
Satisfaction with the lives of elderly nursing homes residents
}

Satysfakcja zżycia starszych mieszkańców Domów Pomocy Społecznej

Dorota Trybusińska, Agnieszka Saracen

Uniwersytet Technologiczno-Humanistyczny w Radomiu, Wydział Nauk o Zdrowiu i Kultury Fizycznej, Zakład Pielęgniarstwa/ University of Technology and Humanities in Radom, Faculty of Health Sciences and Physical Culture, Department of Nursing

Dorota Trybusińska: 0000-0003-4523-4508

Agnieszka Saracen: 0000-0001-9147-3556

CORRESPONDING AUTHOR/AUTOR DO KORESPONDENCJ:

Dorota Trybusińska

Uniwersytet Technologiczno-Humanistyczny w Radomiu

Wydział Nauk o Zdrowiu i Kultury Fizycznej, Zakład Pielęgniarstwa

ul. Chrobrego 27, 26-600 Radom, Polska e-mail: dorotatrybusinska@gmail.com

STRESZCZENIE

Słowa kluczowe:

\section{ABSTRACT}

Key words:

\section{SATYSFAKCJA ZZZYCIA STARSZYCH MIESZKAÑ́CÓW DOMÓW POMOCY SPORECZNEJ}

Wstęp. Starzenie się społeczeństw jest procesem zauważalnym w niemal wszystkich krajach świata. Wiele rodzin nie będzie w stanie pełnić usług opiekuńczych nad osobami starszymi, ciężar opieki spadnie głównie na placówki publiczne i prywatne. Stawia to pracowników domów pomocy społecznej przed licznymi wyzwaniami, aby zapewnić seniorom możliwość poprawy ich satysfakcji życiowej. Cel pracy. Celem przeprowadzonych badań była ocena satysfakcji z życia wśród starszych mieszkańców domów pomocy społecznej z Mazowsza oraz ukazanie zmiennych mających na nią wpływ.

Materiał i metody. Badania zostały przeprowadzone w 2018 r. wśród 250 starszych mieszkańców domów pomocy społecznej z Mazowsza. W trakcie badania posłużono się metodą sondażu diagnostycznego, techniką ankietowania. Narzędziem badawczym była skala Satysfakcji zŻycia (SWLS), skala Oceny Podstawowych Czynności Życiowych wg Katza, skrócony Test Sprawności Umysłowej wg Hodgkinsonsa, kwestionariusz Nadziei Podstawowej (BHI-12), skala Akceptacji Choroby (AIS) oraz kwestionariusz ankiety własnej konstrukcji.

Wyniki. Wśród osób badanych dominującą grupę stanowiły osoby z niskim zadowoleniem z życia (42,8\%). Wykazano istotnie statystyczny związek pomiędzy satysfakcją z życia a wiekiem badanych i wybranymi skalami psychometrycznymi. Nie wykazano takiego związku dla poziomu sprawności, czasu pobytu w DPS oraz wielkości zamieszkiwanej placówki.

Wnioski. Osoby starsze zamieszkujące domy pomocy społecznej na Mazowszu posiadają satysfakcję z życia na poziomie niskim i przeciętnym. Mieszkańcy, którzy wykazywali obniżony poziom satysfakcji z życia, to osoby nowoprzybyłe, najstarsze i chorujące na co najmniej jedną jednostkę chorobową. Działania personelu DPS, przebywającego na co dzień z pensjonariuszami, powinny być ukierunkowane na poprawę odczuwanej przez nich satysfakcji z życia.

satysfakcja z życia, osoby starsze, dom opieki społecznej

\section{SATISFACTION WITH THE LIVES OF ELDERLY NURSING HOMES RESIDENTS}

Introduction. Ageing of societies is a process apparent in nearly all countries worldwide. Many families will not be able to provide care services for the elderly, the burden of care will fall mainly on public and private institutions. This puts employees of nursing homes in front of numerous challenges in order to provide seniors with improvement of their life satisfaction.

Aim. The purpose of the study was to assess the life satisfaction of elderly nursing home residents in the Mazovian region and to demonstrate variables that affect it.

Material and methods. . The research was carried out in 2018 among the 250 elderly nursing home residents from Mazovia. During the test, a diagnostic survey method and a questionnaire technique were used. The research tool was the Satisfaction With Life Scale (SWLS), Katz's Activities of Daily Living Scale, Hodgkinson's Abbreviated Mental Test Score, Basic Hope Inventory (BHI-12), Acceptance of Illness Scale (AIS), and the authors' survey questionnaire.

Results. Among the respondents, the dominant group included people with low life satisfaction (42.8\%). A statistically significant relationship was found between life satisfaction and the age of the respondents and selected psychometric scales. There was no such correlation for the level of mobility, duration of stay at the nursing home and the size of the inhabited facility.

Conclusions. Elderly people living in nursing homes from Mazovia enjoy life satisfaction at a low and average level. The results distinguish three groups of residents exhibiting a lower satisfaction with life, namely, new arrivals, the oldest, and suffering from a minimum of one illness. Nursing home personnel who deal with patients on an everyday basis should aim to improve their life satisfaction. 


\section{INTRODUCTION}

Ageing of societies is a universal phenomenon. It is not abrupt, however, as demographists described these changes as early as several decades ago, nonetheless, its extent has proven far broader than assumed before [1]. In 2017, men in Poland lived for an average of 74.0 years while women for 81.8 years [2].

It should be remembered that the elderly, including nursing home residents, are affected by a number of problems, including greater medical, therapeutic, rehabilitation, welfare, and social support needs and requirements, as well as feelings of loneliness and exclusion from family and public life [3]. As a result, a range of professions faces a number of tasks aimed at providing potential for self-fulfilment and enhanced life satisfaction in the elderly.

Satisfaction with life relates to cognitive assessments or judgments about your own life and is a major factor contributing to the broader construct of mental health [4]. It also serves as a well-being and happiness indicator in both, individuals and societies [5].

The concept of life satisfaction, associated with successful ageing, relates to a balance of life, increasingly important as one ages. Świerżewska reports life satisfaction in seniors depends on a great many factors, both objective and subjective (physical activity, level of education, health condition, personal convictions) [6]. Zielińska-Więczkowska and Kędziora-Kornatowska list health condition, life activities, economic standing, standard of education, and family relations among factors influencing satisfaction with life in old age [7].

There were 44082 nursing home residents aged above 61 at the end of 2016, including 23251 aged more than 74 . Non-public institutions housed 4709 individuals aged above 61 [8].

\section{AIM}

The study was designed to evaluate life satisfaction among older nursing home residents in the Mazovian region and to demonstrate variables that affect it.

\section{MATERIALS AND METHODS}

The survey was conducted among 250 older residents of seven nursing homes from Mazovia between April 2018 and June 2018.

All the surveyed consented in writing. The study employed the diagnostic poll method and the technique of surveying. The Satisfaction with Life Scale (SWLS), Katz's scale of Activities in Daily Living, Hodgkinson's Abbreviated Mental Test Score, the Basic Hope Inventory (BHI-12) by J. Trzebiński and M. Zięba, Acceptance of Illness Scale (AIS) by B. J. Felton, T. A. Revenson and G. A. Hinrichsen adapted into Polish by Z. Juczyński, and the authors' own self-survey questionnaire were the tools.

The Satisfaction with Life Scale (SWLS) by E. Diener, R. A. Emmons, R. J. Larson, and S. Griffin, as adapted into Polish by Z. Juczyński, is a standardised tool consisting of 5 statements. The respondents must determine to what degree they are true for their life by selecting 1 of 7 possible responses ranging from 'I fully disagree' to 'I fully agree' [9].
Katz's scale of Activities in Daily Living helps to describe 6 activities in daily living such as: personal hygiene, self-sufficient dressing and undressing, daily mobility, and control of daily physiological functions [10].

Hodgkinson's Abbreviated Mental Test Score (AMTS) is a screening test serving to assess mental agility and consisting of 10 questions. A respondent scores 1 for each correct answer [11]. The test was utilised for the purpose of initial qualification for the study.

The Basic Hope Inventory (BHI-12) is a self-descriptive tool that consists of 12 statements. The respondents indicate to what extent they agree with the views given by selecting a response on a 5-point scale from 'I absolutely disagree' to 'I absolutely agree'. The higher a score, the greater the basic hope. The basic hope is a personality competence that affects behaviour in the face of major life situations of novelty and/or disintegration of a pre-existing order [12].

The Acceptance of Illness Scale (AIS) contains eight sentences presenting adverse effects of poor health. Respondents indicate on a scale of one to five to what extent they agree with the particular statements. A high score points to a good adjustment to the situation of illness [9].

The authorial survey questionnaire concerned family relations, time, and causes of staying at a nursing home.

Statistical analyses used licensed software IBM SPSS version 25 .

The study draft was approved by the Bioethics Committee at the Rzeszów University in its resolution No. 2018/04/06 of 12 April 2018.

The following criteria of inclusion were applied: gender - women and men; age - 65 and more years of age; duration of stay at a home - more than 1 year; conscious consent to participation in the study; scoring 7 or more at Hodgkinson's Abbreviated Mental Test Score. The exclusion criteria were as follows: less than a year at a nursing home, age below 65, scoring 6 or less at Hodgkinson's Abbreviated Mental Test Score, and lack of a conscious consent to participation in the study.

\section{General sample characteristics}

The number of 250 older nursing home residents were studied, including 157 women $(62.8 \%)$ and 93 men (37.2\%). The average age of the research sample was 71 for males and 75 for females - the latter were statistically significantly older. Katz's scale of Activities in Daily Living showed most members of the group analysed was agile (69.6\%). The men were on average more mobile (78.5\%) than women, though the difference was on the verge of statistical significance (Table 1).

Tab. 1. Efficiency of the respondents according to the Katz questionnaire by sex

\begin{tabular}{|l|c|c|c|c|c|c|}
\hline \multirow{2}{*}{ Efficiency } & \multicolumn{2}{|c|}{ Men } & \multicolumn{2}{c|}{ Women } & \multicolumn{2}{c|}{ Total } \\
\cline { 2 - 7 } & $\mathbf{n}$ & $\%$ & $\mathbf{n}$ & $\%$ & $\mathbf{n}$ & $\%$ \\
\hline disabled & 8 & 8.6 & 26 & 16.6 & 34 & 13.6 \\
\hline moderately disabled & 12 & 12.9 & 30 & 19.1 & 42 & 16.8 \\
\hline agile & 73 & 78.5 & 101 & 64.3 & 174 & 69.6 \\
\hline Total & 93 & 37.2 & 157 & 62.8 & 250 & 100 \\
\hline Chi-square test & \multicolumn{6}{|c|}{0.0565} \\
\hline
\end{tabular}

$\mathrm{n}$ - count, $\%$ - percentage distribution 
The respondents had stayed at their homes for about 7 years on average. The females had lived there for statistically significantly longer (over 2 years) than men had. Health issues clearly prevailed (58.4\%), both with the males and females, among reasons for those surveyed to start living at a nursing home. Nearly a half fewer respondents (28\%) indicated their own independent decisions, though. Both the respondent groups declared distant relatives (women $36.4 \%$, men $26.9 \%$ ), siblings (33.2\% and $41.9 \%$, respectively), and children (31.6\%, 24.7\%) were among their most frequent visitors. Those declaring good and very good relations with their families distinctly prevailed among those studied. However, every $9^{\text {th }}$ woman and every $7^{\text {th }}$ man pointed to very bad family relations. The difference between the genders was not statistically significant (Table 2).

Tab. 2. Relations with family divided by sex

\begin{tabular}{|l|c|c|c|c|c|c|}
\hline \multirow{2}{*}{ Relations with family } & \multicolumn{2}{|c|}{ Men } & \multicolumn{2}{c|}{ Women } & \multicolumn{2}{c|}{ Total } \\
\cline { 2 - 7 } & $\mathbf{n}$ & $\%$ & $\mathbf{n}$ & $\%$ & $\mathbf{n}$ & $\%$ \\
\hline Very good & 24 & 25.8 & 39 & 25.0 & 63 & 25.3 \\
\hline Good & 38 & 40.8 & 73 & 46.8 & 111 & 44.6 \\
\hline Rather bad & 18 & 19.4 & 27 & 17.3 & 45 & 18.1 \\
\hline Very bad & 13 & 14.0 & 17 & 10.9 & 30 & 12.0 \\
\hline Total & 93 & 37.3 & 156 & 62.7 & 249 & 100.0 \\
\hline Chi-square test & \multicolumn{6}{|c|}{0.7844} \\
\hline
\end{tabular}

$\mathrm{n}$ - count, $\%$ - percentage distribution

\section{RESULTS}

\section{The respondents' satisfaction with life}

Those with low life satisfaction dominated among the surveyed (42.8\%), with merely $23.2 \%$ respondents stating their satisfaction with life was high (Table 3).

Tab.3. Sense of life satisfaction among the respondents

\begin{tabular}{|l|c|c|c|}
\hline \multicolumn{1}{|c|}{ Level of life satisfaction } & Sten & $\mathbf{n}$ & $\%$ \\
\hline \multirow{3}{*}{ Low score } & 1 & 23 & 9.2 \\
\cline { 2 - 4 } & 2 & 16 & 6.4 \\
\cline { 2 - 4 } & 3 & 40 & 16 \\
\cline { 2 - 4 } & 4 & 28 & 11.2 \\
\hline \multirow{2}{*}{ Total } & - & 107 & 42.8 \\
\hline \multirow{3}{*}{ Average score } & 5 & 49 & 19.6 \\
\hline \multirow{2}{*}{ Total } & 6 & 35 & 14.0 \\
\hline \multirow{3}{*}{ High score } & - & 84 & 33.6 \\
\cline { 2 - 4 } & 7 & 42 & 16.8 \\
\cline { 2 - 4 } & 8 & 10 & 4.0 \\
\cline { 2 - 4 } & 9 & 2 & 0.8 \\
\cline { 2 - 4 } & 10 & 5 & 2.0 \\
\hline Total & - & 59 & 23.6 \\
\hline
\end{tabular}

$n$ - count, $\%$ - percentage distribution
Both females and males scored similar average satisfaction with life, 18.29 and 17.87 points, respectively (no statistically significant differences between the genders were found $(\mathrm{p}>0.05))$. Average satisfaction with life scores for the whole group were 18.13 points.

Analysis of relations between age and satisfaction with life of the respondents found a statistically significant inversely proportional relationship: the older a home resident, the lower their satisfaction with life. No dependence was detected of mobility rated with Katz's scale of Activities in Daily Living and duration of stay at a nursing home on satisfaction with life ( $p>0.05)$ (Table 4$)$.

Tab. 4. Dependence between Satisfaction with life scale (SWLS) and age, duration of residence at nursing home, and mobility

\begin{tabular}{|l|c|}
\hline & Satisfaction with life \\
\hline Age & $\mathbf{0 . 1 2 9 ^ { * }}$ \\
\hline Time at home residence & -0.021 \\
\hline Katz's mobility scale & 0.104 \\
\hline
\end{tabular}

The study group was divided with regard to sizes of nursing homes they reside at (small homes of up to 100 residents and large homes with 100 or more residents). In small nursing home the average results of the life satisfaction level were 18.47 points, in large nursing home 17.96 points.

Similar numbers of small home residents selected low and average satisfaction with life ( $38.8 \%$ and $40 \%$, respectively). In large nursing homes, $44.8 \%$ of those surveyed pointed to a low satisfaction, followed by $30.3 \%$ with average satisfaction with their life. Statistical analysis comparing satisfaction with life among both resident groupings discovered lack of differences between individuals living at large and small homes in respect of life satisfaction $(\mathrm{p}>0.05)$ (Table 5).

Tab.5. Nursing home size and its residents' satisfaction with life

\begin{tabular}{|l|c|c|c|c|c|}
\hline \multirow{2}{*}{$\begin{array}{c}\text { Level of life } \\
\text { satisfaction }\end{array}$} & \multirow{2}{*}{ Sten } & \multicolumn{2}{c|}{$\begin{array}{c}\text { Residents of small } \\
\text { nursing home }\end{array}$} & \multicolumn{2}{c|}{$\begin{array}{c}\text { Residents of large } \\
\text { nursing homes }\end{array}$} \\
\cline { 2 - 6 } & & $\mathbf{n}$ & $\%$ & $\mathbf{n}$ & $\%$ \\
\hline \multirow{4}{*}{ Low score } & 1 & 5 & 5.9 & 18 & 10.9 \\
\cline { 2 - 6 } & 2 & 7 & 8.2 & 9 & 5.5 \\
\cline { 2 - 6 } & 3 & 11 & 12.9 & 29 & 17.6 \\
\cline { 2 - 6 } & 4 & 10 & 11.8 & 18 & 10.9 \\
\hline Total & - & 33 & 38.8 & 74 & 44.9 \\
\hline \multirow{3}{*}{ Average score } & 5 & 20 & 23.5 & 29 & 17.6 \\
\cline { 2 - 6 } & 6 & 14 & 16.5 & 21 & 12.7 \\
\hline Total & - & 34 & 40 & 50 & 30.3 \\
\hline \multirow{3}{*}{ High score } & 7 & 14 & 16.6 & 28 & 17 \\
\cline { 2 - 6 } & 8 & 2 & 2.3 & 8 & 4.8 \\
\cline { 2 - 6 } & 9 & 0 & 0 & 2 & 1.2 \\
\cline { 2 - 6 } & 10 & 2 & 2.3 & 3 & 1.8 \\
\hline Total & - & 18 & 21.2 & 41 & 24.8 \\
\hline
\end{tabular}

$\mathrm{n}$ - count, $\%$ - percentage distribution 


\section{Satisfaction with life scale and psychometric scales}

Both females and males scored similar average scores on the Disease Acceptance Scale, 23.4 and 25 points, respectively. In the Basic Hope questionnaire the results were also comparable (females 29.2, males 28 points).

Statistical analysis showed a significant relation between the degree of illness acceptance and basic hope and satisfaction with life among nursing home residents. The relationship is directly proportional, that is, the greater the acceptance of illness and basic hope, the greater satisfaction with life (Table 6).

Tab. 6. Sense of life satisfaction and selected psychometric scales

\begin{tabular}{|l|c|}
\hline \multicolumn{1}{|c|}{ Psychometric scale } & test p (Mann-Whitney test) \\
\hline Acceptance of IIIness (AIS) & 0.327 \\
\hline Basic Hope (BHI) & 0.158 \\
\hline
\end{tabular}

$p$-level of significance

\section{DISCUSSION}

Satisfaction with life is an extremely important factor in an individuals' functioning in society. Research into satisfaction of the elderly in Lublin region has demonstrated the seniors were moderately satisfied with their life. Men were more satisfied than women. The authors failed to indicate any links to age, gender, education, or address [13]. A comparable level of life satisfaction was reported by Liberska, who carried out her studies in 2010 and 2016. A majority of those queried exhibited average satisfaction with life and no differences were found between the elderly cohorts compared [14]. Timoszyk-Tomczak and Bugajska researches have not detected any link between satisfaction with life and seniors' age or gender [15]. These authors have not proven any dependence between agility and duration of stay at a nursing home and satisfaction with life, whereas such a dependence was shown for age.

Mirczak and Pikuła have targeted those living in the Lesser Poland countryside. The elderly living there displayed an average satisfaction with life and passage of time had a positive impact. Poorer assessment of their own health, high risk of malnutrition, and poor family relations substantially contributed to low satisfaction [16]. Cognitive processes were the most influential factor in determining life satisfaction among the elderly in rural India. The authors also pointed to social support for individuals, which plays an enormous part in assessing life satisfaction of the elderly [17].

An interesting study has been conducted in Lublin region of 505 elderly primary healthcare patients who exhibit a low and average satisfaction with life [18].

Kok points to small care institutions as more friendly than large ones. They relieve their residents' fears and thereby improve quality of their life [19]. Those results do not match these of this author, where size of institutions had no effect on satisfaction with life.

Herman, Ciszek and Gortat have found an interdependence between nursing home residents' satisfaction with life and levels of loneliness. A growing loneliness is associated with a reduced life satisfaction, especially where loneliness is regarded as difficulties in making and maintaining interpersonal relations [20].

Studies in Taiwan indicate everyday reminiscence therapy among elderly home residents affects their overall satisfaction with life [21].

Research with a group of 1880 elderly Malaysians shows family life (spouses, children) is associated with a greater satisfaction with life than that of lonely residences'. The authors additionally stressed the importance of social support to improving satisfaction with life [22].

\section{CONCLUSIONS}

1. Satisfaction with life of elderly nursing home residents in south Mazovian region is low or average.

2. It has been observed that with age the level of satisfaction with life decreases.

3. Acceptance of one's own condition resulting from accompanying chronic diseases (AIS) and the ability to find oneself in a new life situation (BHI-12), such as living in a DPS (nursing home), have impact on the level of perceived life satisfaction.

\section{Satysfakcja z życia starszych mieszkańców Domów Pomocy Społecznej}

\section{WPROWADZENIE}

Zjawisko starzenia się społeczeństw jest zjawiskiem wszechobecnym. Nie jest to jednak zjawisko nagłe, te zmiany demografowie opisywali już przed kilkudziesięcioma laty, niemniej jednak ich rozmiary okazały się znacznie szersze, niż wcześniejsze założenia [1]. W 2017 r. w Polsce mężczyźni żyli przeciętnie 74,0 lat, natomiast kobiety 81,8 lat [2].

Należy pamiętać, że osoby starsze dotyka wiele problemów, wśród których należy wymienić większe potrzeby medyczne, terapeutyczne, rehabilitacyjne, rosnące potrzeby opieki socjalnej i wsparcia społecznego, a także poczucie samotności, wykluczenia z życia rodzinnego oraz społecznego [3]. Dotyczy to również mieszkańców domów pomocy społecznej. To sprawia, że przedstawiciele różnych profesji stają przed licznymi zadaniami mającymi na celu zapewnienie możliwości samorealizacji i podniesienie satysfakcji z życia osób starszych.

Satysfakcja z życia odnosi się do oceny poznawczej lub osądu własnego życia i jest jednym z kilku ważnych czynników przyczyniających się do szerszej konstrukcji zdrowia 
psychicznego [4]. Służy również jako wskaźnik dobrobytu i szczęścia zarówno jednostek, jak i społeczeństwa [5].

Pojęcie satysfakcji życiowej, powiązane z pomyślnym starzeniem się wiąże się z oceną bilansu życiowego, które nabiera większego znaczenia w starszym wieku. Jak podaje Świerżewska satysfakcja z życia seniorów zależy od wielu czynników zarówno obiektywnych jak i subiektywnych (aktywność fizyczna, poziom wykształcenia, stan zdrowia, osobiste przekonania) [6]. Zielińska-Więczkowska i Kędziora-Kornatowska wśród czynników mających wpływ na satysfakcję życiową w okresie starości wymieniają kondycję zdrowotną, aktywność życiową, sytuację ekonomiczną, poziom wykształcenia i stosunki rodzinne [7].

Z końcem roku 2016 liczba osób po 61 roku życia zamieszkujących placówki domów pomocy społecznej wynosiła 44082 osoby z czego 23251 osób było po 74 roku życia. W podmiotach niepublicznych zamieszkiwało 4709 osób po 61 roku życia [8].

\section{CEL PRACY}

Celem przeprowadzonych badań była ocena satysfakcji z życia wśród starszych mieszkańców domów pomocy społecznej z Mazowsza oraz ukazanie zmiennych mających na nią wpływ.

\section{MATERIAŁ I METODYKA}

Docelowe badania zostały przeprowadzone wśród 250 starszych mieszkańców domów pomocy społecznej, w siedmiu placówkach na Mazowszu, w terminie od kwietnia 2018 r. do czerwca 2018 r.

Wszyscy badani wyrazili pisemną zgodę na udział w badaniu. W badaniach posłużono się metodą sondażu diagnostycznego, techniką ankietowania. Narzędziem badawczym była skala Satysfakcji z Życia (SWLS) autorstwa E. Diener, R. A. Emmons, R. J. Larson, S. Griffin w polskiej adaptacji Z. Juczyński, skala Oceny Podstawowych Czynności Życiowych wg Katza, skrócony Test Sprawności Umysłowej wg Hodgkinsonsa, kwestionariusz Nadziei Podstawowej (BHI-12) autorstwa J. Trzebińskiego i M. Zięby, skala Akceptacji Choroby (AIS) autorstwa B. J. Felton, T. A. Revenson i G. A. Hinrichsen w polskiej adaptacji Z. Juczyński oraz kwestionariusz ankiety własnej konstrukcji.

Skala Satysfakcji z Życia (SWLS) to wystandaryzowane narzędzie, zawierające 5 stwierdzeń. Badany musi ocenić w jakim stopniu odnoszą się one do jego dotychczasowego życia, wybierając 1 z 7 możliwych odpowiedzi, od „zupełnie nie zgadzam się” do „całkowicie zgadzam się” [9].

Skala Oceny Podstawowych Czynności Życia Codziennego wg Katza, służy do opisu 6 podstawowych czynności życiowych takich jak: zdolność utrzymywania higieny, samodzielne ubieranie się i rozbieranie, podstawowa mobilność, kontrolowanie podstawowych czynności fizjologicznych [10].

Skrócony Test Sprawności Umysłowej wg Hodgkinsona (AMTS) jest to przesiewowy test do oceny sprawności umysłowej składający się z 10 pytań. Za każdą prawidłową odpowiedź na pytanie badany otrzymuje 1 pkt. [11].
W projekcie test został wykorzystany do wstępnej kwalifikacji do badań.

Kwestionariusz Nadziei Podstawowej (BHI-12) jest narzędziem samoopisowym, składającym się z 12 stwierdzeń. Badany podaje, w jakim stopniu zgadza się z podanymi poglądami, wybierając za każdym razem jedną z odpowiedzi podanych na 5-stopniowej skali od „zdecydowanie nie zgadzam się” do „zdecydowanie się zgadzam”. Im wyższy wynik, tym większa nadzieja podstawowa. Nadzieja podstawowa jest kompetencją osobowości, która wpływa na zachowania w obliczu ważnych sytuacji życiowych - sytuacje nowości i/lub sytuacji rozpadu dotychczasowego ładu [12].

Skala Akceptacji Choroby (AIS) zawiera osiem zdań przedstawiających niekorzystne konsekwencje złego stanu zdrowia. Badani zaznaczają w skali od jednego do pięciu, w jakim stopniu zgadzają się z poszczególnymi stwierdzeniami. Ocena wyższa wskazuje na dobre przystosowanie się do sytuacji chorobowej [9].

Autorski kwestionariusz ankiety dotyczył relacji rodzinnych, czasu i przyczyny przebywania w DPS.

Analizy statystyczne zostały wykonane przy użyciu licencjonowanego oprogramowania statystycznego IBM SPSS wersja 25.

Projekt badania został zaopiniowany pozytywnie przez Komisję Bioetyczną przy Uniwersytecie Rzeszowskim Uchwała nr 2018/04/06 z dnia 12 kwietnia 2018 roku.

Kryteriami włączenia do badania były: płeć-kobiety i mężczyźni, wiek-65 lat i więcej, czas przebywania w DPS-powyżej 1 roku, świadoma zgoda na udział w badaniach, uzyskanie 7 lub więcej punktów wg Skróconego Testu Sprawności Umysłowej wg Hodgkinsonsa. Kryteriami wyłączenia $z$ badania były: czas przebywania w DPS-krótszy niż 1 rok, wiek-poniżej 65 roku życia, uzyskanie 6 lub mniej punktów wg Skróconego Testu Sprawności Umysłowej wg Hodgkinsonsa, brak świadomej zgody na udział w badaniach.

\section{Charakterystyka ogólna próby}

Przebadano 250 starszych mieszkańców domów pomocy społecznej. Wśród nich było 157 kobiet $(62,8 \%)$ i 93 mężczyzn (37,2\%). Średnia wieku w badanej grupie wynosiła 71 lat dla mężczyzn i 75 lat dla kobiet - kobiety były istotnie statystycznie starsze. Skala Oceny Podstawowych Czynności Życiowych wg Katza wykazała, że najliczniejszą grupą wśród analizowanych osób były osoby sprawne $(69,6 \%)$. Biorący udział w badaniu mężczyźni byli przeciętnie sprawniejsi $(78,5 \%)$ od kobiet, ale różnica była na granicy istotności statystycznej (tab. 1).

Tab. 1. Stan sprawności badanych wg kwestionariusza Katza a płeć

\begin{tabular}{|l|c|c|c|c|c|c|}
\hline \multirow{2}{*}{ Stan sprawności } & \multicolumn{2}{|c|}{ mężczyzna } & \multicolumn{2}{c|}{ kobieta } & \multicolumn{2}{c|}{ razem } \\
\cline { 2 - 8 } & $\mathbf{n}$ & $\%$ & $\mathbf{n}$ & $\%$ & $\mathbf{n}$ & $\%$ \\
\hline Poważnie niesprawny & 8 & 8,6 & 26 & 16,6 & 34 & 13,6 \\
\hline Umiarkowanie niespr. & 12 & 12,9 & 30 & 19,1 & 42 & 16,8 \\
\hline Sprawny & 73 & 78,5 & 101 & 64,3 & 174 & 69,6 \\
\hline Razem & 93 & 37,2 & 157 & 62,8 & 250 & 100 \\
\hline Test chi-kwadrat & \multicolumn{6}{|c|}{0,0565} \\
\hline
\end{tabular}

n-liczebność, \% - rozkład procentowy 
Badani przebywali w DPS średnio około 7 lat. Kobiety mieszkały w DPS znamiennie statystycznie dłużej (ponad 2 lata) niż mężczyźni. Wśród przyczyn, które skłoniły ankietowanych do zamieszkania w DPS, zdecydowanie dominowały (zarówno wśród kobiet jak i mężczyzn) problemy zdrowotne $(58,4 \%)$. Na samodzielną decyzję wskazało już prawie o połowę mniej respondentów (28\%). Obie grupy mieszkańców deklarowały wśród najczęściej odwiedzających ich osób dalszą rodzinę (kobiety $36,4 \%$, mężczyźni 26,9\%), rodzeństwo (odpowiednio 33,2\%, 41,9\%) oraz dzieci $(31,6 \%, 24,7 \%)$. Wśród badanych zdecydowanie dominowały osoby deklarujące dobre i bardzo dobre stosunki z rodziną. Jednak co 9 kobieta i co 7 mężczyzna wskazywali na bardzo złe stosunki rodzinne. Różnica wyników pomiędzy płciami nie była istotna statystycznie (tab. 2).

Tab. 2. Stosunki rodzinne badanych w zależności od płci

\begin{tabular}{|l|c|c|c|c|c|c|}
\hline \multirow{2}{*}{ Stosunki z rodziną } & \multicolumn{2}{|c|}{ Mężczyzna } & \multicolumn{2}{c|}{ Kobieta } & \multicolumn{2}{c|}{ Razem } \\
\cline { 2 - 8 } & $\mathbf{n}$ & $\%$ & $\mathbf{n}$ & $\%$ & $\mathbf{n}$ & $\%$ \\
\hline Bardzo dobre & 24 & 25,8 & 39 & 25,0 & 63 & 25,3 \\
\hline Dobre & 38 & 40,8 & 73 & 46,8 & 111 & 44,6 \\
\hline Raczej złe & 18 & 19,4 & 27 & 17,3 & 45 & 18,1 \\
\hline Bardzo złe & 13 & 14,0 & 17 & 10,9 & 30 & 12,0 \\
\hline Razem & 93 & 37,3 & 156 & 62,7 & 249 & 100,0 \\
\hline Test chi-kwadrat & \multicolumn{6}{|c|}{0,7844} \\
\hline
\end{tabular}

$\mathrm{n}$-liczebnośc, \% - rozkład procentowy

\section{WYNIKI}

\section{Satysfakcja z życia wśród badanych}

Wśród osób badanych dominującą grupę stanowily osoby z niską satysfakcją z życia (42,8\%), jedynie $23,2 \%$ respondentów określiło swoje zadowolenie z życia jako wysokie (tab. 3).

Tab.3. Poczucie satysfakcji z życia wśród badanych

\begin{tabular}{|l|c|c|c|}
\hline Poziom satysfakcji z życia & Sten & $\mathbf{n}$ & $\%$ \\
\hline \multirow{4}{*}{ Wyniki niskie } & 1 & 23 & 9,2 \\
\cline { 2 - 4 } & 2 & 16 & 6,4 \\
\cline { 2 - 4 } & 3 & 40 & 16,0 \\
\cline { 2 - 4 } & 4 & 28 & 11,2 \\
\hline Razem & - & 107 & 42,8 \\
\hline \multirow{2}{*}{ Wyniki przeciętne } & 5 & 49 & 19,6 \\
\hline \multirow{2}{*}{ Razem } & 6 & 35 & 14,0 \\
\hline \multirow{3}{*}{ Wyniki wysokie } & - & 84 & 33,6 \\
\hline \multirow{3}{*}{ Razem } & 7 & 42 & 16,8 \\
\cline { 2 - 4 } & 8 & 10 & 4,0 \\
\cline { 2 - 4 } & 9 & 2 & 0,8 \\
\cline { 2 - 4 } & 10 & 5 & 2,0 \\
\hline
\end{tabular}

$\mathrm{n}$ - liczebność, \% - rozkład procentowy
Zarówno kobiety, jak i mężczyźni uzyskiwali podobne średnie wyniki poziomu satysfakcji z życia, odpowiednio 18,29 i 17,87 punktów (nie wykazano istotnych statystycznie różnic między płciami $(p>0,05))$. Średnie wyniki poziomu satysfakcji z życia dla całej grupy wyniosły 18,13 punktów.

Analiza związku pomiędzy wiekiem i poczuciem satysfakcji z życia wśród badanych wykazała istotny statystycznie, odwrotnie proporcjonalny związek, im starszy rezydent DPS tym mniejsza jego satysfakcja z życia. Nie wykazano zależności pomiędzy poziomem sprawności ocenionym Skalą Oceny Podstawowych Czynności Życia Codziennego wg Katza i czasem pobytu osoby starszej w DPS a jej satysfakcją z życia (p>0,05) (tab. 4).

Tab. 4. Analiza związku pomiędzy wiekiem, czasem pobytu w DPS i poziomem sprawności a poczuciem satysfakcji zżycia wśród mieszkańców DPS

\begin{tabular}{|l|c|}
\hline & Poczucie satysfakcji z życia \\
\hline Wiek & $\mathbf{0 , 1 2 9 *}$ \\
\hline Czas pobytu w DPS & $-0,021$ \\
\hline Poziom sprawności wg. Katz & 0,104 \\
\hline
\end{tabular}

Grupę badanych osób podzielono ze względu na wielkość DPS, który zamieszkują (małe DPS do 100 osób i duże DPS 100 osób i więcej). W małych DPS średnie wyniki poziomu satysfakcji z życia wyniosły 18,47 punktów, w dużych DPS 17,96 punktów.

W małych DPS podobna liczba rezydentów wskazała na niskie i przeciętne zadowolenie z życia (odpowiednio $38,8 \%$ i $40 \%)$. W dużych DPS $44,8 \%$ ankietowanych wskazało na niskie zadowolenie z życia, kolejną grupą byli mieszkańcy z przeciętnym zadowoleniem z życia $30,3 \%$. Analiza statystyczna porównująca poziom satysfakcji z życia wśród mieszkańców obu grup wykazała brak różnic pomiędzy osobami zamieszkującymi duże i małe DPS w zakresie satysfakcji z życia ( $>>0,05)$ (tab. 5).

Tab.5. Wielkość DPS a poczucie satysfakcji z życia jego mieszkańców
\begin{tabular}{|l|c|c|c|c|c|}
\hline $\begin{array}{c}\text { Poziom } \\
\text { satysfakcji } \\
\text { ż̇ycia }\end{array}$ & \multirow{2}{*}{ Sten } & \multicolumn{2}{|c|}{ Małe DPSy } & \multicolumn{2}{c|}{ Duże DPSy } \\
\cline { 2 - 6 } & & $\mathbf{n}$ & $\%$ & $\mathbf{n}$ & $\%$ \\
\hline \multirow{4}{*}{ Wyniki niskie } & 1 & 5 & 5,9 & 18 & 10,9 \\
\cline { 2 - 6 } & 2 & 7 & 8,2 & 9 & 5,5 \\
\cline { 2 - 6 } & 3 & 11 & 12,9 & 29 & 17,6 \\
\cline { 2 - 6 } & 4 & 10 & 11,8 & 18 & 10,9 \\
\hline Razem & - & 33 & 38,8 & 74 & 44,9 \\
\hline \multirow{3}{*}{ Wyniki przeciętne } & 5 & 20 & 23,5 & 29 & 17,6 \\
\cline { 2 - 6 } & 6 & 14 & 16,5 & 21 & 12,7 \\
\hline Razem & - & 34 & 40 & 50 & 30,3 \\
\hline \multirow{4}{*}{ Wyniki wysokie } & 7 & 14 & 16,6 & 28 & 17 \\
\cline { 2 - 6 } & 8 & 2 & 2,3 & 8 & 4,8 \\
\cline { 2 - 6 } & 9 & 0 & 0 & 2 & 1,2 \\
\cline { 2 - 6 } & 10 & 2 & 2,3 & 3 & 1,8 \\
\hline Razem & - & 18 & 21,2 & 41 & 24,8 \\
\hline
\end{tabular}

$\mathrm{n}$ - liczebność, \% - rozkład procentowy 


\section{Skala satysfakcji z życia a skale psychometryczne}

Zarówno kobiety, jak i mężczyźni uzyskiwali podobne średnie wyniki w skali Akceptacji Choroby, odpowiednio 23,4 i 25 punktów. W kwestionariuszu Nadziei Podstawowej wyniki również były porównywalne (kobiety 29,2, mężczyźni 28 punktów).

Analiza statystyczna wykazała istotny związek pomiędzy stopniem akceptacji choroby i nadzieją podstawową a poczuciem satysfakcji z życia wśród mieszkańców DPS. Związek ten jest wprost proporcjonalny, czyli im większa akceptacja choroby i nadzieja podstawowa tym większy poziom satysfakcji z życia (tab. 6).

Tab. 6. Poczucie satysfakcji z życia a wybrane skale psychometryczne

\begin{tabular}{|l|c|}
\hline \multicolumn{1}{|c|}{ Skale psychometryczne } & p testowe (test Man-Whitney'a) \\
\hline Akceptacja choroby (AIS) & 0,327 \\
\hline Nadzieja podstawowa (BHI) & 0,158 \\
\hline
\end{tabular}

p-poziom istotności

\section{DYSKUSJA}

Satysfakcja z życia jest niezwykle ważnym czynnikiem wiążącym się z funkcjonowaniem jednostki w społeczeństwie. Badania nad satysfakcją z życia osób starszych mieszkających w województwie lubelskim ukazały, że seniorzy byli zadowoleni ze swojego życia w stopniu umiarkowanym. Mężczyźni byli w większym stopniu zadowoleni niż kobiety. Autorzy nie wykazali powiązania takich czynników jak wiek, płeć, wykształcenie i miejsce zamieszkania na omawianą kwestię [13]. Podobny poziom satysfakcji z życia wykazała w swoich badaniach Liberska przeprowadzając badania porównawcze w 2010 i 2016 roku. Większość badanych cechowała się przeciętnym zadowoleniem z życia i nie wykazano różnic $\mathrm{w}$ poziomie pomiędzy porównywanymi kohortami ludzi starszych [14]. Badania Timoszyk-Tomczak i Bugajskiej nie wykazały powiązania satysfakcji z życia z wiekiem i płcią seniorów [15]. W badaniach własnych nie wykazano zależności pomiędzy poziomem sprawności i czasem pobytu osoby starszej w DPS a jej satysfakcją z życia zaś taką zależność wykazano dla wieku.

Mirczak i Pikuła skierowali swoje badania do mieszkańców małopolskich wsi. Osoby starsze zamieszkujące je, wykazały się przeciętną satysfakcją z życia a upływ czasu miał na nią pozytywny wpływ. Na niskie zadowolenie znaczący wpływ miała gorsza ocena swojego zdrowia, ograniczenia w funkcjonowaniu, duże ryzyko niedożywienia oraz złe relacje rodzinne [16]. Procesy poznawcze były najbardziej wpływowym czynnikiem w określaniu satysfakcji z życia wśród osób starszych z obszarów wiejskich w Indiach. Autorzy badania wskazali również na wsparcie społeczne jednostki, które odgrywa ogromną rolę w ocenie satysfakcji z życia osób w podeszłym wieku [17].

Ciekawe badania przeprowadzono w województwie lubelskim. Zostały one przeprowadzone na 505 starszych pacjentach podstawowej opieki zdrowotnej, którzy cechowali się niskim i przeciętnym poziomem zadowolenia z życia [18].
Kok badając mieszkańców małych i dużych placówek opieki wskazuje te pierwsze, jako bardziej przyjazne. Wiążą się one ze zmniejszeniem lęku u rezydentów, a co za tym idzie ze zwiększeniem ich jakości życia [19]. Wyniki te nie korespondują z badaniami własnymi, gdzie rozmiar placówki nie miał wpływu na poziom satysfakcji z życia.

Herman, Ciszek i Gortat wykazali wzajemną zależność pomiędzy satysfakcją z życia mieszkańców domu pomocy społecznej a ich poziomem samotności. Wzrost poczucia osamotnienia łączy się z pogorszeniem satysfakcji z życia, szczególnie gdy samotność jest rozumiana jako trudność w nawiązywaniu i podtrzymywaniu relacji z innymi osobami [20].

Badania przeprowadzone na Tajwanie wskazują, że prowadzenie codziennie terapii reminiscencyjnej wśród starszych mieszkańców domów opieki wpływa na ogólny wzrost satysfakcji z życia [21].

Badania przeprowadzone na grupie 1880 starszych mieszkańców Malezji pokazuje, że życie w rodzinie (małżonek, dzieci) wiązało się z lepszą satysfakcją życiową niż samotne zamieszkiwanie. Dodatkowo autorzy wskazali na znaczenie wsparcia społecznego dla podniesienia satysfakcji z życia [22].

\section{WNIOSKI}

1. Osoby starsze zamieszkujące domy pomocy społecznej na Mazowszu posiadają satysfakcję z życia na poziomie niskim i przeciętnym.

2. Zaobserwowano, że wraz $z$ wiekiem spada poziom odczuwanej satysfakcji z życia.

3. Akceptacja własnego stanu wynikająca z towarzyszących chorób przewlekłych (AIS) oraz umiejętność odnalezienia się w nowej sytuacji życiowej (BHI-12), jak na przykład zamieszkanie w DPS, mają wpływ na poziom odczuwanej satysfakcji z życia.

\section{REFERENCES/PIŚMIENNICTWO}

1. Błędowski P. Starzenie się jako problem społeczny. Perspektywy demograficznego starzenia się ludności Polski do roku 2035. [w:] Mossakowska M, Więcek A, Błędowski P. red. Aspekty medyczne, psychologiczne, socjologiczne i ekonomiczne starzenia się ludzi w Polsce. Poznań: Termedia Wydawnictwa Medyczne; 2012, s.11-23.

2. Główny Urząd Statystyczny. Trwanie życia w 2017 r. Warszawa 2018, s.13.

3. Wasilewska-Ostrowska K. Samotność osób starszych w kontekście zmian demograficznych. Kultura i Edukacja. 2013; 4(97): 234-244.

4. Murthy RS, Manoel Bertolote J, Epping-Jordan J, et al. The World Health Report 2001 - Mental Health: New Understanding, New Hope. Geneva, Switzerland: World Health Organization; 2001. Retrieved from http://www.who.int/whr/2001/en/, dostęp 12.05.2019.

5. Kahneman D, Krueger AB, Schkade D, et al. Toward National Well-Being Accounts. The American Economic Review. 2004; 94 (2): 429-434.

6. Świerżewska D. Satysfakcja z życia aktywnych i nieaktywnych osób po 60. roku życia. Psychologia Rozwojowa. 2010; 15(2): 89-99.

7. Zielińska-Więczkowska H, Kędziora-Kornatowska K. Determinanty satysfakcji życiowej w późnej dorosłości - w świetle rodzimych doniesień badawczych. Psychogeriatria Polska. 2010; 7(1): 11-16.

8. MPiPS-05, Wybrane informacje o ponadgminnych oraz gminnych domach pomocy społecznej, środowiskowych domach pomocy, mieszkaniach chronionych i placówkach całodobowej opieki prowadzonych w ramach działalności gospodarczej i statutowej wg stanu na dzień 31.XII.2015. Wrzesień 2016, za: https://www.mpips. gov.pl, dostęp:16.08.2018.

9. Juczyński Z. Narzędzia pomiaru w promocji i psychologii zdrowia. Wyd. 2. Warszawa: Pracownia Testów Psychologicznych; 2012. 
Dorota Trybusińska, Agnieszka Saracen

10. Kachaniuk H. Całościowa ocena geriatryczna. [w:] Materiały dydaktyczne dla uczestników kursu specjalistycznego „Kompleksowa pielęgniarska opieka nad pacjentem z najczęstszymi schorzeniami wieku podeszłego", opracowane w ramach projektu systemowego: Rozwój kwalifikacji i umiejętności kadry pielęgniarskiej w kontekście zmian epidemiologicznych będących następstwem starzejącego się społeczeństwa. Warszawa 2013, s.22-23, 72.

11. Romanik W, Łazarewicz M. Wersja polska Skróconego Testu Sprawności Umysłowej (AMTS) - problemy metodologiczne, Psychiatr Psychol Klin. 2017; 17(3): 203-207.

12. Trzebiński J, Zięba M. Kwestionariusz Nadziei podstawowej - BHI-12. Pracownia Testów Psychologicznych Polskiego Towarzystwa Psychologicznego, Warszawa 2003.

13. Pawlikowska-Łagód K, Dąbska 0, Humeniuk E, Sak J. Satysfakcja z życia osób starszych mieszkających w województwie lubelskim. Geriatria. 2017; 11: 183-189.

14. Liberska H. Wybrane podmiotowe i kontekstualne uwarunkowania satysfakcji z życia w okresie późnej dorosłości. Badanie porównawcze. Rocznik Andragogiczny. 2016; 23: 217-230.

15. Timoszyk-Tomczak C, Bugajska B. Satysfakcja z życia a perspektywa przyszłościowa w starości. Opuscula Sociologica. 2013; 2(4): 83-95.

16. Mirczak A, Pikuła N. Satysfakcja z życia starszych osób mieszkających w wybranych miejscowościach wiejskich województwa małopolskiego. Pielęgniarstwo i Zdrowie Publiczne. 2014; 4(4): 321-326.

17. Banjare P, Dwivedi R, Pradhan J. Factors associated with the life satisfaction amongst the rural elderly in Odisha, India. Health and Quality of Life Outcomes Volume. 2015; 13(201): doi: 10.1186/ s12955-015-0398-y.

18. Nowicki GJ, Młynarska M, Ślusarska B, i wsp. Analiza poziomu satysfakcji z życia osób powyżej 65. roku życia, pacjentów Podstawowej Opieki Zdrowotnej (POZ) w zależności od wybranych cech socjodemograficznych. Gerontologia Polska. 2016; 24: 264-268.

19. Kok JS, Nielen MM, Scherder EJA. Quality of Life in Small - Scaled Homelike Nursing Homes: an 8 - Month Controlled Trial. Health Qual Life Outcomes. 2018; 16: 38.

20. Herman A, Ciszek P, Gortat M. Samoocena i poczucie samotności z zadowolenie z życia u pensjonariuszy domów pomocy społecznej. Lublin: Annales Uniwersitatis Mariae Curie-Skłodowska Lublin-Polonia. 2018; 32(1): 219-227.

21. Ching-Teng Y, Chia-Ju L, Hsiu-Yueh L. Effects of structured group reminiscence therapy on the life satisfaction of institutionalized older adults in Taiwan. Soc Work Health Care. 2018; 57(8): 674-687. doi: 10.1080/00981389.2018.1475439.

22. Kooshiar H, Yahaya N, Hamid TA, et al. Living arrangement and life satisfaction in older malaysians: the mediating role of social support function. PLOS ONE. 2012; 7:e43125. doi: 10.1371/journal.pone.0043125.
Manuscript received/Praca zgłoszona do czasopisma: 12.07.2019

Manuscript accepted/Praca zaakceptowana do druku: 17.11.2019

Translation/Tłumaczenie: Jacek Spólny 